\title{
Reengineering and Reinventing both Democracy and the Concept of Life in the Digital Era
}

\author{
Yiannis Laouris
}

\section{The Need to Reinvent Democracy in the Digital Era}

\subsection{Direct Democracy; A Recipe for Chaos}

Democracy of the twenty-first century refers almost exclusively to the right to take part in the political process (i.e., the right to vote). Nevertheless, the percentages of citizens who choose to exert this basic human right have fallen in Europe to an average of less than $80 \%$ (Poland and Switzerland close to 50\%) and in the US to around $60 \%$ (European Commission 2013). At the same time, the European political-economic system fails to secure employment for 26 million people (ca. $12 \%$ ), (European Commission 2013). It is, to say the least, disgraceful that some politicians blame the youth for their reduced interest in politics and diminishing participation in societal matters, when the politicians are the ones who have failed to put in place accountable, transparent and efficient mechanisms and processes to secure one of the most basic human rights: the right to work. Next to corruption, the unprecedented crises of institutions and values and the lack of accountability, one of the root causes underlying the failure of current systems of governance to respond to challenges is the fact that those we elect as our representatives fail to lobby and promote for the issues for which they have been chosen. In a series of co-laboratories using the Structured Democratic Dialogue Process (SDDP) (Future Worlds Center 2012) with 20-25 participants in each working collaboratively for 3-7 days, it was repetitively observed that root inhibitors of the current systems of governance include primarily: The fact that political systems did not evolve like everything else around us; Lack of accountability of those in power; Corruption

\footnotetext{
Y. Laouris $(\square)$

Future Worlds Center, Cyprus Neuroscience \& Technology Institute, Nicosia, Cyprus

e-mail: Laouris@futureworldscenter.org

5 Promitheos, 1065, Lefkosia, Cyprus

L. Floridi (ed.), The Onlife Manifesto, 
and conflicts of interest; Corporate control of the means of democracy. Follow-up co-laboratories exploring design options for ideal futures, revealed as most powerful factors mechanisms such as: Laws voted directly by people; Inclusiveness, dialogue, co-decision in local communities and their representation in decisionmaking; Continuous passive and active participation in the political process via online platforms; Independent interactive media created by citizens for citizens, and even suggestions for the end of political parties as institutions. It should not come as a surprise that citizens focus on ideas that seek to put in place better controls on those managing power and direct connections between people and law-making and/ or decision-making processes. It is a broadly accepted thesis that the digital era has rendered most types of intermediaries obsolete or it has replaced them with technology; why not use technology to also bypass our representatives or even bring an end to political parties as institutions (Petridou et al. 2012) ${ }^{1}$ ?

Since the digital era opens tremendous possibilities for real-time feedback, frequent polling and online voting for virtually any matter from anywhere on the planet, in the minds of many, more voting equals more democracy. Direct democracy, a term coined recently, refers to a specific (one of many) model of democratic participation in which all citizens have equal access, equal voice, and equal voting power on all issues. We argue that if we were to adopt such an approach when taking political or other important group decisions, we would most probably create chaos. The direct democracy paradigm should therefore be rigorously distinguished and differentiated from a paradigm that demands massive, but at the same time authentic democratic participation. The term "authentic" refers to the demand that all relevant stakeholders are given both opportunity to participate in a genuine manner, and voice to argue in a structured and documented way over issues that could potentially influence their lives. As simple as this might sound, we currently do not have the theoretical grounds or the technical means to implement such a model. The challenges spread in multiple dimensions. For example, how do we identify and engage those whose lives will be influenced by whatever is being discussed or it will be decided for every particular situation? How do we weight their voice without violating principles of democracy? In other words, how do we design and implement systems, which guarantee that voting outcomes will always both rely on wisdom and will at the same time, be fair to everyone involved? Furthermore, how do we protect the authenticity of citizens' opinions and their anonymity? More importantly, how do we achieve true and not elusive equality (vide infra)?

Crozier, Huntington and Watanuki in their 1975 "The Crisis of Democracy" book (Crozier et al. 1975) report that Willy Brandt believed that "Western Europe has only 20 or 30 more years of democracy left in it; after that it will slide, engineless and rudderless, under the surrounding sea of dictatorship, and whether the dictation comes from a politburo or a junta will not make that much difference." According to the same authors, a senior British official stated that "If Britain continues to be

\footnotetext{
${ }^{1}$ This factor ended up as one of the most influential ideas in the "Re-inventing Democracy in the Digital Era" SDDP, co-organized with the Digital Futures Task Force of the European Commission with participants from the European Youth Forum.
} 
unable to resolve the seemingly un-resolvable problems of inflation-cum-prospective depression, observed, parliamentary democracy would ultimately be replaced by a dictatorship. And Takeo Miki warned in his first days in office that "Japanese democracy will collapse unless major reforms can be carried out and the people's confidence in politics be restored."

Many contemporary authors, using indicators of citizenship and democratic deficits, also suggest that the current system of governance is not democratic at all and that wide-reaching and pervasive problems threaten the legitimacy and stability of the political system (Dalton 2006; Durant 1995; Macedo et al. 2005; Rimmerman 2001). Several centuries after Rousseau, present-day authors consent that democracy does not exist anywhere in the world, even today (Rousseau 1923) it has indeed never existed (Magas 2013); except once in Athens just after Ephialtes ${ }^{2}$ invented it, and it lasted for only about 140 years. Ephialtes (Wikipedia 2013) was literally the nightmare of the monarchists of those times, and his name in Greek translates to 'nightmare'. We dare suggest that this is truer today than ever before. We put forward the thesis that this is why the systems of governance should and they are about to change!

True democracy is the nightmare of our contemporary politicians.

The above questions constitute grand challenges of our times that need to be addressed with high priority before the current systems of governance collapse completely. Some of the most relevant challenges, central to the EC's 2020 horizon strategies, to UNESCO, to UN and to practically every future-looking organization on the planet, are discussed in the next section.

\subsection{Grand Challenges Towards Reengineering or Even Reinventing Democracy}

\subsubsection{Challenge \#1: Identify and Engage the Right Stakeholders}

The first challenge demands that everybody who is a stakeholder in a situation must have the right to participate in any dialogue, deliberation, or decision on matters that are of concern to him or her. Indeed, the science of structured dialogic design predicts "the capacity of a community of stakeholders to implement a plan of action effectively depends strongly on the true engagement of all whose lives might be affected" (Flanagan and Christakis 2009; Laouris et al. 2008). Disregarding their participation is not only unethical, but also any plans made are bound to fail (Laouris et al. 2008). We therefore need to develop systems that guarantee the authentic

\footnotetext{
${ }^{2}$ Even though Ephialtes was assassinated in $461 \mathrm{BC}$ and therefore did not live to participate in the Golden Age of Athens ( $480 \mathrm{BC}-404 \mathrm{BC}$ ), he is credited as one of the founders of true democracy.
} 
involvement of those whose lives might be influenced by any decisions taken. In the era of globalization and hyper-connectivity, these are not trivial problems. Should Europeans (or any others) have a say in what happens in Africa? Are the citizens of one European member state stakeholders in decisions regarding the management of the economy of another member state? Current political, economic and environmental deadlocks have challenged previously widely accepted notions of who the stakeholders in a particular situation are. Even if we admit that stakeholders might extend outside previously well-defined defined geographical boundaries, how do we design systems in which their voting power is somehow weighted in ways that are fair and just for everybody? Furthermore, what if decisions affect the "lives" of entities without a voice (living or non-living)? How do we secure their "participation" in a dialogue (May 2011; Wasilewski 2007) that "concerns" them?

\subsubsection{Challenge \#2: Voting Leads to Fair and Wise Results}

Decision making based on majority voting has been the prevailing and unquestionable model of democracy for centuries. We know that the majority's opinion is neither always just for everybody nor always right. Many societies, including the European Union, as well as the company law, have developed policies and mechanisms to protect the rights of minorities. However, now that today's technology theoretically allows everybody to vote any time on any issue, we face a new threat: that of creating chaos. Interestingly, according to Özbekhan, Jantsch, and Christakis, who conceptualized the original prospectus of the Club of Rome titled "The Predicament of Mankind"(Christakis 2006), the premature selection of corrective actions to problems (i.e., premature voting) based on popular vote leads to an extrapolated future, which differs significantly from an ideal vision. This is because we fail to capture and to address the inter-relations, inter-connections and interactions between individual aspects (sub-problems) of the problematic situation, which we are trying to improve. Popular voting on complex issues often results in erroneous priorities ("EPE: The Erroneous Priorities Effect: (Dye and Conaway 1999)). However, with no better model at hand, questioning the validity of popular voting opens Pandora's box. Nevertheless, the hyper-connectivity era encourages us to reconsider concepts like those of fairness and equality and to reengineer the concept of democracy.

Democracy has its roots in ancient Athens. Contrary to general belief, that model was not entirely based on popular voting. Athenians of the Golden Age were engaged collectively in searching and carefully examining meanings and alternatives together through a process they called "deliberation." They aimed to fully understand the underlying problems, clarify the debatable situation and achieve consensus. They justified the correctness of their decision because they trusted their collective wisdom. The collectively agreed course of action was backed up by all and it was considered unthinkable or even unethical to go against it, not because it was a decision eventually ordered by their king, but a decision taken democratically and shared by the great majority of those considered 
stakeholders. This model was workable because the number of citizens participating was relatively small.

More than two millenniums later, we need to reinvent democracy in ways that millions can participate effectively. To achieve this we must guarantee that the individual has access to all relevant information, alternatives, and arguments necessary for him to her to vote responsibly. Courses of action should be chosen based on their capacity to facilitate change towards a collectively defined and agreed desired ideal future state. In sum, votes should not only be weighted in some way, to engage all relevant stakeholders fairly; moreover the process that precedes voting should capitalize on what we call collective wisdom.

Scientists now associated with the Institute of twenty-first century Agoras have been developing methodologies ("Interactive Management"; (Alexander 2003; Warfield and Cárdenas 1994)), Interpretive Structural Modeling algorithms (Warfield 1982) and software (Christakis 2000; Warfield 1994) for almost 30 years. The use of special software is critical in freeing participants from focusing on logistics, serving real-time documentation and more importantly taking decisions regarding the optimal choice of questions to deal with in order to minimize the time of engagement to produce meaningful results (Christakis and Dye 2008). The Digital Futures Task Force of the European Commission has also recently launched one of the most ambitious ever, online engines, inviting large-scale public consultation called FUTURIUM (Digital Futures Task Force 2012) (see policies below).

\subsubsection{Challenge \#3: Protecting Anonymity and Authenticity of Opinions}

It is common experience that workshop or dialogue reporters are not only unable to record everything that is being said, but even worse, they more often than not distort the meaning and/or the intention of the proposer, therefore contributing to the feeling that one's ideas are not appreciated (Laouris 2012). Technology allows high fidelity and high-resolution conservation of the exact words, sounds, videos, but also of the semantic meanings of what is said. Once digitalized, ideas can be processed in many ways. Innovations in the digitalization of ideas will probably lead to a new revolution in our struggle to exploit our collective intelligence. In a very similar way, even though voting is presumed to be confidential and a matter of individual choice, especially in small communities, political parties can estimate who voted what by re-constructing simple puzzles comprised of peoples' networks, public statements and personal interests. In the era of digital hyper-connectivity and with digital privacy disappearing, there will be greater need to protect one's thoughts, opinions, judgments and eventually choices and decisions.

\subsubsection{Challenge \#4: Achieve True and Not Elusive Equality}

Three words, liberté, égalité, fraternité (French for liberty, equality, fraternitybrotherhood), captured the essence of the French Revolution. Those who sacrificed their lives dreaming for a better world have not done so in the name of an abstract 
meaning of democracy, but for a concrete vision of real freedom, authentic equality and true brotherhood between all people. More than two centuries have passed and one would be barely justified to claim freedom, equality and brotherhood among twenty-first century citizens. The millennium hype that the emergence of information technologies would serve to close economic, educational, democratic, digital, and social gaps on our planet was not confirmed (Laouris and Laouri 2008). Alvin Toffler's (Toffler and Toffler 1995) transition to the Information Age, defined as the point when "progress depends more on the mind than on the muscle," happened long time ago, but people still work either a lot more than $8 \mathrm{~h}$ a day or they remain hopelessly unemployed. Likewise, Marx's dream for a stateless, classless society he called communism, where everyone can have what he or she needs, disappeared with the Berlin Wall.

Our digital futures challenge not only concepts such as human/technology relationships, presence, friendship, responsibility, agency, liability and capability, but also basic concepts of our existence such as freedom, equality, mortality (see next section) and even purpose. What does it mean to be free, or to be equal in the digital era? Achieving true freedom and equality are enormous challenges that unless addressed within the context of the 2020 horizon, our world will have no future. Designing technologies and implementing policies to safeguard the true individual human rights and freedoms constitute probably the greatest challenges for our future societies.

\subsection{Policy Implications}

\subsubsection{Authentic Participation}

As we have implied above, votes should probably not only be weighted to justly engage all relevant stakeholders; moreover, the process that precedes voting should be designed in structured ways and supported by innovative technologies to support participants capitalize on what we refer to as collective intelligence mal (Malone 2006) and collective wisdom (Christakis 1996; Flanagan and Christakis 2009). Research in these fields is rising rapidly. Scientists at the Center for Collective Intelligence at MIT (Malone 2006) founded by Thomas Malone in 2006 focus on the very basic research question: How can people and computers be connected so that-collectively - they act more intelligently than any individuals, groups, or computers have ever done before? The Wisdom Research at the University of Chicago (20072011) led by John Cacioppo (Cacioppo 2007) aspired to define wisdom, to explore the relationship between expertise and wisdom and to discover how experience could increase wisdom. The Institute for twenty-first century Agoras founded in 2003 by Aleco Christakis (Christakis 2003), is a leader in world-wide applications of their Structured Dialogic Design Process (SDDP) methodology (originally developed by John Warfield and Alexander N. Christakis in the early 1970s (Christakis 1996; Christakis 1973; Warfield and Cárdenas 1994). The SDDP enables a diverse group of stakeholders to engage in a democratic and structured dialogue, reach a 
consensus and take actions, especially when participants represent diverse points of view, competing interests and different backgrounds. In Europe there is still very little research on these issues. The most visible initiatives come from the EC. The Onlife Initiative has probably created some momentum towards identifying the concepts that might require re-engineering in the digital era. The concept of freedom has been central in the Onlife Manifesto: "our selves are both free and social, i.e., that freedom does not occur in a vacuum, but in a space of affordances and constraints: together with freedom, our selves derive from and aspire to relationships and interactions with other selves, technological artifacts, and the rest of nature. As such, human beings are 'free with elasticity', to borrow an economic notion." The challenge is how to manage and fine-tune this elasticity. The FUTURIUM, also an initiative of the Digital Task Force, invites citizens from across Europe to reflect on future European policies and propose and discuss ideal futures. The aim is to design rather than to anticipate or predict the future. Will this initiative become a new standard in Europe? Moreover, will FUTURIUM expand to include sophisticated algorithms to secure authentic participation? Stakeholder analysis, weighted voting, collective intelligence, collective wisdom, and management of complex societal systemic problems are just a few of the disciplines that need to be supported and developed further. Even when the theoretical challenges are resolved, we will need to develop techno-social systems like the ones' under development by the Agoras Group that implement accompanying theory.

\subsubsection{Respect Human Cognitive Limitations}

Since the time that cognitive psychologist George Miller (Miller 1956) discovered that our short-term memory can only hold seven, plus or minus two, items and John Warfield (Warfield 1988) proposed that this number falls down to three items when we are expected to perform any operations on them (such as compare them), scientists have been aware of this eminent cognitive limitation. The overwhelming bombardment of today's youth (and not only) with information through digital screens that demand their attention a significant part of a day (according to EUKIDS Online research the average time spent online by $9-16$ year olds is $88 \mathrm{~min}$ per day in front of computers; (Livingstone et al. 2011) has brought to light another great limitation of our cognitive abilities: our attentional abilities are also quite limited! It should therefore come as no surprise that the prevalence of the attention deficit syndrome (i.e., ADHD) has increased significantly over the past two decades of the information revolution. Furthermore, with the number of options increasing and the impact of our choices becoming less predictable, we need access to artificially intelligent agents to support us in evaluating options. At the same time, with the number of "intelligent," "living" digital creatures surrounding us also increasing exponentially, we might even have to fight for attention and personalization.

It is therefore not accidental that the Onlife Manifesto recommends, "Societies must protect, cherish and nurture humans' attentional capabilities," and concludes "more collective attention should be paid to attention itself." 


\subsubsection{Technologies to Enhance Human Cognitive Limitations}

Future citizens will have to take a lot more decisions than they do today and they will have to do this a lot more frequently. Alternatives are becoming not only progressively more complex and their characteristics concealed and convoluted, but in addition one's experience, perception of the world, and even one's own reality becomes increasingly diminished and subject to manipulation. If today's citizens feel powerless to participate in the decision making process and their voice having no reasonable possibility to be heard, how would citizens of the future feel like if we do not address these problems? The question is what would it take to design new systems of governance in which people's authentic and real wishes can be taken into account. Future citizens should somehow become capable of harvesting their collective intelligence and their collective wisdom rather than allowing personal interests and pathetic behaviors of individuals prevail in the decision making process.

Within the next decade we ought to develop tools that would allow us to browse and interact not only with information but also with simulations and predicted futures that might emerge depending on the choices we might make. Certainly, we will be forced to rely almost exclusively on technology. New forms of systemic vulnerabilities will arise from the increasing reliance on informational infrastructures. Power games in online spheres can also lead to undesirable consequences, including the disempowering of people through data manipulation. The repartition of power and responsibility among public authorities, corporate agents, and citizens should be more balanced. Research and tools to combat these threats become an absolute priority.

Finally, since technology will be essential, the democratization of the processes of design and development of new technologies becomes a requirement. We must guarantee access and simplicity of interfaces.

\section{Should We Re-Engineer the Concept of Life in the Computational Era}

The distinction between life and death, between the living and the nonliving, has always been blurred in the spheres of the divine and the imagination. By contrast, biology has offered a distinctive definition that has worked well for many centuries and served research advancements and developments. This simple definition distinguishes the living by its capacity to grow (through metabolism), respond (to stimuli), adapt (through natural selection), and reproduce. A more accurate definition describes life with seven properties: (a) made up of cells; (b) capable of reproduction; (c) based on genetic code; (d) exhibiting growth and development; (e) needing materials and energy; (f) responsive to its environment; and g) maintaining an internal balance. Interestingly, the concept of an inevitable death is not usually included in the properties of life; it is nonetheless implied.

While researchers operate with the above definition, they also often use terms that portray something as if it were alive, even with the knowledge that it may not 
meet all the above criteria. Researchers do this with a conscious understanding that the distinction is known and that people are aware of it. There are a number of archetypal examples, which we introduce briefly in the next paragraphs.

Are Seeds or DNA Alive? Seeds are made of cells. They can, in principle, develop into living organisms that metabolize and grow; they have a genetic code; and they maintain their internal balance. In many ways, a seed may be considered to be alive. There is a definite period of viability when, if not planted and germinated, a seed will eventually die. Some seeds survive only a few days, whereas seeds recovered from cold peat bogs have germinated after thousands of years. Nonetheless, seeds do not grow and do not respond to stimuli (at least, not in detectable ways). Therefore, they are not alive, as such, but they are potentially alive. In analogous ways, Deoxyribonucleic acid (DNA), as the code of life, is also only potentially alive because it also does not meet several of the above criteria for living organisms. For example, it does not develop or grow and does not metabolize. Nevertheless, it manages to replicate and propagate and thereby secure the continuation of life. In both cases, these two entities carry life within them, but they are not alive as such. Nevertheless, the recent complete sequencing of the DNA of a horse that has lived 780,000 years ago by Ludovic Orlando and Eske Willerslev (Orlando and Willerslev 2013) opens the door for bringing back to life pre-historic humans therefore challenging the concepts of life and death.

Is Plato Alive Today? Many might argue that Plato (like countless others) is alive today, at least in the minds of the millions of people who have read, internalized, and reproduced his ideas and philosophy. In some sense, he could therefore be considered alive. Speaking more precisely, his ideas are alive but not he himself. His ideas continue to develop and grow in the sense that they "metabolize" ideas coming from contemporary authors and use them to grow. His ideas respond in undeniable ways when confronted with present-day challenges; some of his ideas adapt to contemporary realities and therefore survive longer, and they are continually being reproduced. One could argue that they could be coded and that they manage to maintain their internal cohesion. Where, then, is the line drawn in the distinction between alive and dead? Even though his ideas meet many of the conditions of life, they cannot be regarded as a living organism, because they are not constrained within a finite body made out of cells, among other reasons. It is not in Plato's mind that his ideas continue to live. Instead, they evolve and propagate only in the minds of so many others.

The distinction implicitly made above is that whatever processes are the objects of study, they must take place within the original entity (in the above case, in Plato's mind). Is this a necessary requirement in our era, however? Clark and Chalmers, advocates of the extended mind hypothesis (Clark and Chalmers 1998), would argue that the container of Plato's ideas (i.e., his mind) has simply changed (to the minds of many). What, then, if technology allows a person's mind to work while inside a different host (e.g., a constrained silicon circuit or a distributed network) after the body of that person dies? Would that entity meet the criteria used to describe something as being alive? It would be the same mind, and for all practical considerations 
capable of learning, reacting, developing, and adapting eternally. It will, however, violate the requirement that a living organism is made up of cells. If we choose to stick to this requirement, we can postpone the need to re-engineer our concepts.

Computer technology and ICT in particular have created conditions for digital as well as physical artifacts to not only remain "alive" for very long (virtually indefinite) periods, but also, more importantly, to be able to express many of the properties previously reserved only for the living. The invention of the internet has kindled irreversible transformations in at least two dimensions. In one dimension, it created a grid that connects people, knowledge, and machines. The internet of things added the nonliving, the environment, and even nature at large to this grid. In another dimension, the internet facilitated the development of new technologies and new spaces. Virtually unlimited data, information, and knowledge, as well as the products of thoughts (e.g., digital footprints) and actions (e.g., traces of actions while browsing through or interacting in cyberspace), are, for all practical purposes, immortal. Sooner than many imagine, rudimentary versions of "human minds" will be capable of continuing their own lives, "interacting" with other people or beings and environments and learning from their actions. These developments invite humanity to rethink many of the concepts previously considered invariable, as summarized in the following questions and discussed in some more detail in the following sections:

- What does it mean to be alive? (Does the concept of life need to be revisited?)

- What does it mean to be human? (Is the human really something more than just information? If yes, then what?)

- If the processes responsible for the emergence of the mind become immortal, can the mind then be separated from its container?

- If humans become immortal, what are the consequences for sustainability?

\subsection{What Does It Mean to Be Alive?}

This foundational question cannot receive a definitive answer using today's concepts, but addressing it is useful for dealing with the challenges. Nevertheless, to continue to teach the seven properties of life as if they were sufficient to describe the living is not only counterproductive, it is also misleading.

\subsection{What Does It Mean to Be Human?}

The 1999 movie Bicentennial Man, based on Isaac Asimov's novella published in 1975, and the movie A.I., written, directed, and produced by Steven Spielberg in 2001, have already provoked people into rethinking not only whether a humanoid is alive, but also, more importantly, whether a humanoid should be granted rights reserved only for humans. Furthermore, taking up Hannah Arendt's task of 
reconsidering "the human condition from the vantage point of our newest experiences and most recent fears," the discovery that humans may be nothing more than information calls precisely for a re-engineering of the concept of what it means to be human in the computational era. This discussion invites us to reflect upon ourselves and not only define whatever makes us human but also, more importantly, to identify those special characteristics that clearly distinguish us from non-humans and which we would like to preserve (Laouris 2013).

\subsection{Mind and Body}

Can the mind exist without a body? Aristotle proposed that the mind (soul) cannot exist outside a body and dies with it, whereas Descartes maintained a rigid distinction between the realms of mind and matter. Scientists today describe light as being both wave and particles, and quantum mechanics has questioned the foundations of physics as we knew it for centuries by proposing that particles exist in all states at once (in coherent superposition) and that a cat can be alive and dead at the same time! The deliberations that led to the Onlife Manifesto have also encouraged the members of this think tank to favor dualities over the classical oppositional dichotomies. Consequently, if we manage 1 day to upload a human mind to a machine (or the net), it will mean that the mind can be separated from the body but at the same time will be an admission that the mind requires a body, albeit a different one. All the same, the challenges and implications will be the object of many studies to come.

\subsection{Immortality and Sustainability}

One could argue that were humans to live longer or even become biologically immortal, that would be devastating for the environment and for sustainability. Moreover, many ethical questions arise, such as whether humans have the right to live longer than other creatures, whether people should establish rules and conditions to terminate life or agree to euthanasia, and how to determine who or what should live and die.

\subsection{Grand Challenges Towards Achieving Immortality}

Scientists and technologists aspire to achieve immortalities of different types using completely different theoretical groundings and technologies. Each approach poses different conceptual challenges. 


\subsubsection{Challenge \#1: Decelerate or Stop Biological Aging}

Scientists work on many different paths to decelerate or completely end the process of biological aging. To begin with, we use different definitions for aging, which of course impose different points of intervention. These, in turn, have different effects on the need to reconsider relevant concepts. For example, if aging and cell death are pre-programmed, then breaking that code opens up questions about whether someone placed that code there for a reason and whether breaking that code brings us close to that creator. By contrast, if aging is simply a process of metabolic and cellular burnout and overuse, we may not need to reconsider any concepts. Moreover, if we view aging as a multidimensional process of physical, psychological, and social change, then all of these changes need to be taken into consideration when talking about aging. For example, according to Kyriazis (Kyriazis 2003, 2005), chaos theory and entropy imply that more information will lead to more intellectual complexity, as well as more biological redundancy, i.e., less risk of aging and death.

\subsubsection{Challenge \#2: Replace Biological with Manufactured Tissues}

This has already begun, with heart pacemakers, metallic joints, bionic limbs, eye and ear transplants, etc. Research also goes one step further in enhancing human capabilities by using technologies that are not necessarily designed as human homomorphs, as in the case of exoskeletons. Are emerging cyborgs or, eventually, robots still human? Should we draw a line or accept, as Minsky (Minsky 2004) suggested, "robots will inherit the earth, but they will be our children"?

\subsubsection{Challenge \#3: Regenerative Medicine}

A term attributed to William Haseltine (founder of Human Genome Sciences; (Viola et al. 2003)), regenerative medicine refers to the "process of replacing or regenerating human cells, tissues, or organs to restore or establish normal function" (Mason and Dunnill 2008). The theoretical and technological approaches range from attempts to regenerate damaged tissues and organs in the body and/or stimulating the body's own repair mechanisms to heal previously irreparable tissues or organs, to replacing damaged tissue or organs either by growing (manufacturing) them in the lab using scaffolding technologies or "printing" (see also below) them layer by layer.

Repairing the Body from Inside At first glance, the idea that nanorobots inside our body will repair whatever needs to be repaired does not affect our concepts of life, human, or identity. What, however, if these robots are controlled from outside? What about the concept of free will, for example?

Manufacturing Organs Organs are engineered using decellularizing a living organ (removing cells to leave a clean extracellular structure) to keep only the skeleton. Stem cells are grown within the structure and re-create the organ. Artificially cre- 
ated structures are also being used as scaffolds to engineer, for example, heart valves or bladders. Three-D organ printers are also no longer science fiction. For example, Anthony Atala at the Wake Forest Institute for Regenerative Medicine (see, for example, (Nakamura et al. 2005; Xu et al. 2009)) has been trying to print heart valves, kidneys, livers, and other tissues using a technology analogous to inkjet printers, injecting human cells instead of nano-sized droplets of ink. The idea of manufacturing or "printing" human organs to replace those aging or malfunctioning opens up new conceptual challenges with regard to what it means for an organ to be alive, the constancy of the identity of the recipient, and even the mind-body question. What's more, the idea that someday we might develop printers that "print" printers (i.e., reproduction) challenges the very concept of life.

\subsubsection{Challenge \#4: Transfer the Mind to a Machine}

This usually refers to the process of transferring or copying a conscious mind from a brain to a non-biological substrate. Even though still considered by many as farfetched science fiction, in some ways it has already begun. In the not-too-distant future, digital agents may represent us to some extent, behaving and acting like us. With the added functionality of learning from their mistakes, they will have a life of their own. Thus, a rudimentary self will continue to live in cyberspace even after our death. Once we have reached the point when an entirely, conscious self can be transferred, we will have managed to transfer the human mind to a machine. At that point, we will face new questions, such as, what happens if the biological equivalent continues to live?

\subsection{Policy Implications}

\subsubsection{Life Extension}

In a world in which artifacts and information survive much longer than the human body, there will be increasing pressure to also extend the human lifespan. As Floridi (Chapter "Commentary by Ganascia") observes, "more people are alive today than ever before," while at the same time about 100,000 people die every day because of aging. Anticipating a significant prolongation of the human lifespan or wishing for immortality opens up a Pandora's Box of countless challenges related to evolution and sustainability. Research that aims at the prolongation of life expands in different directions, ranging from DNA manipulations to manufactured biological or bionic organ replacements, to nano-technology and stem cell-technology based treatments. The ethical and sustainability challenges that accompany these developments require not only relevant research but also appropriate attention and policies (Hildebrandt: Chapter "Hyperhistory and the Philosophy of Information Policies"). We might have to reconsider the right to live longer than other creatures on earth (or in the universe), the right to interfere with nature, and the right to take evolution into human hands. 


\subsubsection{Authentic Participation in Decision Making and Governance}

Today's technologies enable many more people to live longer and better lives and therefore to be able to interact with each other for longer periods. Such technologies also allow them to share and interact in multiple public (real and virtual) spaces. This increased connectivity, in conjunction with greater access to information and knowledge, inevitably enables more people to participate in debates and decisions. Such developments also increase the possibilities for disagreements and conflicts, however. The science of structured dialogic design discussed in part one of this chapter predicts that the capacity of a community of stakeholders to implement a plan of action effectively depends strongly on the genuine engagement of all those whose lives might be affected (Flanagan and Christakis 2009; Laouris 2012) and that disregarding their participation is not only unethical but also means that any plans made are bound to fail (Laouris et al. 2008). Therefore, the concept and the means to such authentic participation will need to be reconsidered and redefined. We are in urgent need of technologies that would enable massive collaboration to accelerate decision making (Laouris and Christakis 2007) and, consequently, positive social change. The struggle to extend public spaces, in which humans interact and increase affordances and freedoms, must be accompanied by parallel developments in methodologies and technologies that can effectively guarantee that wisdom will always prevail in our choices and actions.

\subsubsection{Access to Technologies}

The intelligence, size, and every other physical and mental characteristic of all species follow normal distributions with restricted standard deviations. Technological developments that significantly enhance humans might, even in the short term, significantly distort these distributions, especially if the economic, social, educational, and other gaps between the rich and the poor on the planet remain as large as they are. Despite the technological progress, elderly people and people with disabilities (COST Action-219ter 2010; Laouris and Michaelides 2007) as well as the public at large (COST Action-298 2007; Laouris et al. 2007) do not benefit sufficiently. Therefore, societies need to pay increasingly more attention to issues of access, accessibility and wide participation.

\subsubsection{Privacy in a Globally Connected World}

Data and information immortality pose enormous challenges to the concept of privacy. Privacy has two aspects: the power to control what information the individual wishes to reveal and the power to erase information that belongs to or concerns the individual. While the first becomes increasingly complicated, the second is virtually impossible today because of legal and technological constraints. For example, how are future humans protected from invisible manipulations that can take place 
via extensions of or attachments to their body and mind? Nothing remains strictly private or public. Privacy depends on the circumstances or even on one's financial caliber. How is privacy defined when it comes to artificial agents or interfaces connecting human brains with other brains or systems? The legal system and people's wisdom in general will need to catch up with developments in technology if they are ever going to be able to tackle questions of decision making and privacy in a globally connected world.

\subsubsection{The Right to Digital Euthanasia}

The feasibility of life extension increases the challenges to privacy because the chances that an individual might wish to delete something about him- or her-self from the net undoubtedly grows with increasing life spans. Trying to solve this problem, which at first glance appears rather technical, creates enormous new challenges. The power to decide to erase any type of information from the internet is one of the greatest controversies in the discussions regarding EU Data protection regulation. In addition, the technical aspect is a lot more complicated than one would imagine. This is because in order to be able to trace and delete data that an individual has created, it would be necessary for the data produced by any individual (human or nonhuman) to bear some kind of signature and/or leave footprints behind, even when the data are copied, moved, or otherwise processed by others at any later stage. This opens a Pandora's Box of issues about privacy and anonymity. Furthermore, consider the case of more complex digital creatures, originally created by someone. If a digital agent evolves and acquires new knowledge, experiences, and skills, it starts to become something independent from its creator. Such possible futures force us to reconsider popular worldviews and the concept of what it means for a being to be alive or dead (or somewhere in between) or for a being to exist or not to exist (or something in between), as well as who has the right to decide about the life, death, existence, or extermination of such forms of life/information.

\subsection{What Is Human?}

With the blurring between the living and the nonliving, between biologicallynature-made and technologically-nature-made artifacts, comes an urgent need to identify explicitly the true and deep characteristics that define the human and distinguish people from the nonhuman. For example, only humans are concerned with the meaning of life and the inevitability of death. Moreover, the search for gratification and the ability to create conditions to develop rights and codes of ethics are found only in humans, although there are rudimentary versions in some primates and dolphins. As far as we knew until recently, only humans experience dreams while they sleep, have a theory of mind, and express and understand humor and irony. These are just a few examples of characteristics generally reserved for humans. The ques- 
tion is whether we invest enough in research to understand the effects of hyperconnectivity and of the extension of public spaces with practically infinite parallel virtual spaces on these presumably human properties. How many government policies or societal priorities care and protect the characteristics that are fundamental to the concept of being human? It must be top priority not only to research and understand, but more importantly to nurture and safeguard whatever truly distinguishes humans from everything else in this universe.

Open Access This chapter is distributed under the terms of the Creative Commons Attribution Noncommercial License, which permits any noncommercial use, distribution, and reproduction in any medium, provided the original author(s) and source are credited.

\section{References}

Alexander, G. C. 2003. Interactive management: An emancipatory methodology. Systems Practice and Action Research 15:111-122.

Cacioppo, J. 2007. Defining wisdom project. http://wisdomresearch.org. Accessed 30 Jun 2013.

Christakis, A. N. 1973. A new policy science paradigm. Futures 5:43-558.

Christakis, A. N. 1996. A people science: The CogniScope system approach. Systems: Journal of Transdisciplinary Systems Sciences 1:16-19.

Christakis, A. N. 2000. Cogniscope software. http://www.globalagoras.org/what-wedo/agorasprocess/structured-dialogic-design-software/. Accessed 30 Jan 2014.

Christakis, A. N. 2003. Institute for 21 st century Agoras. http://www.globalagoras.org/about. Accessed 30 Jan 2014.

Christakis, A. N. 2006. A retrospective structural inquiry of the predicament of humankind; prospectus of the club of Rome. In Volume 1: Rescuing the enlightenment from Itself, eds. J. P. van Gigch and Janet McIntyre-Mills, 93-122. US: Springer.

Christakis, A. N., and K. Dye. 2008. The Cogniscope ${ }^{\mathrm{TM}}$ lessons learned in the Arena. In Dialogue as a collective means of design conversation, eds. P. M. Jenlink and B. H. Banathy, 187-203. US: Springer.

Clark, A., and D. J. Chalmers. 1998. The extended mind. Analysis 58:7-19.

COST Action-219ter. 2010. Accessibility for all to services and terminals for next generation mobile networks. In European Commission: COST Office. http://www.tiresias.org/cost219ter/. Accessed 30 Jan 2013.

COST Action-298. 2007. Participation in the broadband society! In European Commission: COST Office. http://www.cost298.org. Accessed 30 Jun 2013.

Crozier, M. J., S. P. Huntington, and J. Watanuki. 1975. The crisis of democracy. New York: New York University Press.

Dalton, R. J. 2006. Citizen politics: Public opinion and political parties in advanced industrial democracies. Washington, D.C.: CQ Press.

Digital Futures Task Force. 2012. Futurium. In European Commission. http://ec.europa.eu/digitalagenda/futurium/. Accessed 30 Jun 2013.

Durant, R. F. 1995. The democracy deficit in America. Political Science Quarterly 110:25-47.

Dye, K. M., and D. S. Conaway. 1999. Lessons learned from five years of application of the CogniScope ${ }^{T M}$ approach to the food and drug administration. Paoli: CWA Ltd.

European Commission E. 2013. Unemployment statistics. http://epp.eurostat.ec.europa.eu/statistics_explained/index.php/Unemployment_statistics. Accessed 30 Jun 2013. 
Flanagan, T. R., and A. N. Christakis. 2009. The talking point: Creating an environment for exploring complex meaning. Charlotte: Information Age Publishing.

Future Worlds Center. 2012. Reinventing_democracy. http://www.futureworlds.eu/wiki/Reinventing_democracy. Accessed 30 Jun 2013.

Kyriazis, M. 2003. Practical applications of chaos theory to the modulation of human ageing: Nature prefers chaos to regularity. Biogerontology 4:75-90.

Kyriazis, M. 2005. Clinical anti-aging hormetic strategies. Rejuvenation Research 8:96-100. doi:10.1089/rej.2005.8.96..

Laouris, Y. 2012. The ABCs of the science of structured dialogic design. International Journal of Applied Systemic Studies 4:239-257.

Laouris, Y. 2013. What does it mean to be human (in preparation).

Laouris, Y. and A. Christakis. 2007. Harnessing collective wisdom at a fraction of the time using Structured Dialogic Design Process in a virtual communication context Int. J. Applied Systemic Studies, 1(2), 131-153.

Laouris, Y., and R. Laouri. 2008. Can information and mobile technologies serve to close the economic, educational, digital, and social gaps and accelerate development? World Futures 64:254-275. doi:10.1080/02604020802189534.

Laouris, Y., and M. Michaelides. 2007. What obstacles prevent practical broadband applications from being produced and exploited? In Towards an inclusive future: Impact and wider potential of information and communication technologies, ed. R. Patrick, 281-299. Brussels: COST.

Laouris, Y., M. Michaelides, and B. Sapio. 2007. What are the obstacles that prevent the wide public from benefiting and participating in the broadband society? In Innovating for and by users, eds. J. Ierson, E. Mante-Meijer, E. Loos, and B. Sapio, 171-180. Luxembourg: COST Office.

Laouris, Y., R. Laouri, and A. Christakis. 2008. Communication praxis for ethical accountability: The ethics of the tree of action: Dialogue and breaking down the Wall in Cyprus. Systems Research and Behavioral Science 25:331-348.

Livingstone, S., L. Haddon, A. Görzig, and K. Ólafsson. 2011. Risks and safety on the internet: The perspective of European children: Full findings and policy implications from the EU Kids Online survey of 9-16 year olds and their parents in 25 countries. EU Kids Online, Deliverable D4. London: EU Kids Online Network.

Macedo, S., A. Alex-Assensoh, J. M. Berry, M. Brintnall, D. E. Campbell, L. R. Fraga, et al. 2005. Democracy at risk: How political choices undermine citizen participation, and what we can do about it. Washington, D.C.: Brookings Institution Press.

Magas, G. 2013. Comment on TEDTalk: Rory Stewart: Why democracy matters. http://www.ted. com/talks/rory_stewart_how_to_rebuild_democracy.html?c=589811. Accessed 30 Jan 2014.

Malone, T. 2006. The MIT center of collective intelligence. http://cci.mit.edu. Accessed 30 Jan 2014.

Mason, C., and P. Dunnill. 2008. A brief definition of regenerative medicine. Regenerative Medicine 3:1-5.

Miller, G. A. 1956. The magical number seven, plus or minus two: Some limitations on our capacity for processing information. Psychology Review 63:81-97.

Minsky, M. L. 2004. Will robots inherit the earth? Yes, but they will be our children. Canada: Scientific American (Oct).

Nakamura, M., A. Kobayashi, F. Takagi, et al. 2005. Biocompatible inkjet printing technique for designed seeding of individual living cells. Tissue engineering 11:1658-1666. doi:10.1089/ ten.2005.11.1658..

Orlando, L., and E. Willerslev. 2013. First horses arose 4 million years ago. http://www.nature. com/news/first-horses-arose-4-million-years-ago-1.13261. Accessed 30 Jun 2013.

Petridou, E., E. Michail, M. Georgiou, and D. Psilla. 2012. Reinventing democracy in the digital era. Nicosia: Future Worlds Center http://www.futureworlds.eu/wiki/SDDP_Reinventing_Democracy_in_the Digital_Era. Accessed 30 Jan 2014.

Rimmerman, C. A. 2001 . The new citizenship: Unconventional politics, activism, and service. 2 nd ed. Boulder: Westview Press.

Rousseau, J.-J. 1923. The social contract and discourses. Pg. 1761. London: Dent. 
Thorseth, M. 2011. Rights to a Green Future Uncertainty, Intergenerational Human Rights and Pathways to Realization (ENRI-Future). An ESF Research Networking Programme. http:// www.greenrights.nl. Accessed 30 Jan 2014.

Toffler, A., and H. Toffler. 1995. Creating a new civilization: The politics of the third wave. Atlanta: Turner Publishing.

Viola, J., B. Lal, and O. Grad. 2003. The emergence of tissue engineering as a research field. Arlington: National Science Foundation.

Warfield, J. N. 1982. Interpretive Structural Modeling. In: Group Planning and Problem-Solving Methods in Engineering, ed. S. A. Olsen, 155-201. New York: Wiley.

Warfield, J. N. 1988. The magical number three, plus or minus zero. Cybernetics and Systems 19:339-358.

Warfield, J. N. 1994. Interpretive Structural Modeling (ISM) software. http://www.gmu.edu/ depts/t-iasis/ism/ism.htm. Accessed 30 Jan 2014.

Warfield, J., and A. Cárdenas. 1994. A handbook of interactive management. Palm Harbor: Ajar Publishing Company.

Wasilewski, J. 2007. Dialogue for reconciliation and the management of complex issues: The coevolution of MIID communities (multi-centered, interlinked, inclusive, discursive communities). Peace Reports: ICU Peace Research Institute (PRI) Newsletter 5:3-4, 6.

Wikipedia. 2013. Ephialtes. http://en.wikipedia.org/wiki/Ephialtes. Accessed 30 Jan 2014.

Xu, T., J. Rohozinski, W. Zhao, et al. 2009. Inkjet-mediated gene transfection into living cells combined with targeted delivery. Tissue engineering Part A 15:95-101. doi:10.1089/ten. tea.2008.0095. 